\title{
Incidence of hemorrhagic complications with use of a radial compression device: a cohort study
}

\author{
Incidência de complicações hemorrágicas com o \\ uso de pulseira de compressão radial: estudo de coorte \\ Incidencia de complicaciones hemorrágicas con el \\ uso de pulsera de compresión radial: estudio de cohorte
}

Eliane Silva Machado Córdova ${ }^{1}$, Lidiane Rodrigues dos Santos, Daiane Toebe ${ }^{2}$, Maria Antonieta Pereira de Moraes Emiliane Nogueira de Souza ${ }^{3}$

How to cite this article:

Córdova ESM, Santos LR, Toebe D, Moraes MAP, Souza EN. Incidence of hemorrhagic complications with use of a radial compression device: a cohort study. Rev Esc Enferm USP. 2018;52:e03410. DOI: http://dx.doi.org/10.1590/S1980-220X2017041003410

${ }^{1}$ Fundação Universitária de Cardiologia do Rio Grande de Sul, Instituto de Cardiologia, Porto Alegre, RS, Brazil.

2 Fundação Universitária de Cardiologia do Rio Grande de Sul, Instituto de Cardiologia, Programa de Residência Multiprofissional em Saúde, Porto Alegre, RS, Brazil.

${ }^{3}$ Universidade Federal de Ciências da Saúde de Porto Alegre, Porto Alegre, RS, Brazil.
Corresponding author:

Emiliane Nogueira de Souza

Universidade Federal de Ciências da Saúde

Rua Sarmento Leite, 245, Sala 401a

CEP 90050-170 - Porto Alegre, RS, Brazil

emilianes@ufcspa.edu.br

\begin{abstract}
Objective: To examine the incidence of hemorrhagic complications in patients undergoing radial cardiac catheterization and using a hemostatic device for arterial compression. Method: A prospective cohort study conducted with patients undergoing elective cardiac catheterization in two hemodynamic laboratories in southern Brazil. The TR Band ${ }^{\circledR}$ radial compression device was used during 4 hours for hemostasis of the arterial puncture site. Hematomas and minor bleeding were the outcomes evaluated. Results: A total of 244 patients were evaluated. The mean age was $63.5 \pm 10.9$ years, $61.9 \%$ were male, $73.8 \%$ had systemic arterial hypertension (SAH) and $42.8 \%$ were dyslipidemic. Type I hematoma occurred in $1.2 \%$ of patients and minor bleeding in $9 \%$ after removal of the device. There was no significant association between hematomas and bleeding, and patients who used oral anticoagulants $(p=0.604)$ and prior use of antiplatelets $(p=0.958)$. Conclusion: The use of the hemostatic device for radial artery compression was safe in clinical practice and there was a low incidence of hematomas and minor bleeding after radial coronary angiography.
\end{abstract}

\section{DESCRIPTORS}

Cardiac Catheterization; Hemodynamics; Radial Artery; Cardiovascular Nursing. 


\section{INTRODUCTION}

The radial pathway has been widely used in percutaneous cardiovascular procedures, since it allows performing complex interventions with reduction of intensity and duration of hemostasis after arterial pressure, and is associated with lower rates of vascular complications and major bleedings with potential impact on morbidity and mortality ${ }^{(1-4)}$. Another important factor of this approach is the preferential choice by patients, because it provides greater comfort in recovery after the intervention by enabling early ambulation and shorter hospitalization time ${ }^{(5-6)}$. However, the small caliber of the artery makes puncture difficult and requires a longer learning curve compared to femoral access, but these challenges are often overcome with operators' experience ${ }^{(7-8)}$. Vascular complications and radial artery occlusion (RAO) are some of the reported complications that may predispose the patient to extremity ischemia. However, occurrences of this magnitude are infrequent and should not be considered limiting. Data from the literature describe a low incidence of RAO when diagnosed clinically or by ultrasound ${ }^{(1,9-10)}$. Multiple radial artery catheterizations, larger doses of heparin, longer compressions, and use of a larger caliber introducer are the most common predisposing factors for these complications ${ }^{(11)}$. Another concern in the interventional practice, although smaller, is the duration of bleeding and the delay of hemostasis after arterial compression.

Among the available methods of radial compression widely used in hemodynamics laboratories, there is manual compression, the use of occlusive dressings with elastic bandage and hemostatic devices. These may reduce the time to reach hemostasis and prevent complications related to arterial patency. Previous studies comparing compression devices of the arterial puncture site between patients undergoing percutaneous procedures indicate a slightly higher incidence of bleeding and hematoma with use of compression dressings compared to hemostatic devices, without prejudice to the patency of the artery used and without prolonging hospital stay ${ }^{(12-13)}$. The TR Band ${ }^{\circledR}$ radial compression device was developed by Terumo Medical, is easy to handle, hygienic and reusable, an advantage in reducing hospital costs compared to other compression techniques ${ }^{(10)}$.

The different methods and devices available have been well accepted in clinical practice. However, each service or team seeks to develop safe and effective strategies according to their reality and availability. Thus, sharing systematized care practices in the interventionist cardiology scenario can contribute to improvements in care lines involving patients undergoing percutaneous intervention with repercussions on quality and care safety. In light of the above and the need to evaluate a new technology handled by nursing, this study was designed for checking the incidence of hemorrhagic complications in patients undergoing radial cardiac catheterization and using a compression device.

\section{METHOD}

\section{TYPE OF STUDY}

Prospective, non-comparative cohort study.

\section{Population}

Patients of both sexes, aged 18 years or older, who underwent elective cardiac catheterization (elective coronary angiography) with an initial radial airway approach, and used the TR Band ${ }^{\circledR}$ hemostatic device were included. Patients who underwent angioplasty soon after the diagnostic examination were excluded.

\section{SCENARIO}

The study was conducted in two hemodynamic laboratories in southern Brazil. One of these laboratories provides public and private health care, is located in the northeast region of Rio Grande do Sul, and has five hemodynamic doctors and two nurses. The other is located in the region of Planalto Catarinense, provides private health care exclusively, and has two hemodynamic doctors and one nurse.

\section{SAmple CALCULATION}

The sample size calculation was based on a previous study ${ }^{(12)}$, in which there was a $3.4 \%$ incidence of hemorrhagic complications. The following were considered: $95 \%$ confidence interval, a margin of error of $1.5 \%$, and an approximate population of 400 patients/year. It was estimated a need to evaluate 234 patients (including $20 \%$ of losses).

\section{Data collection}

Subjects were included in the study after the diagnostic examination, when they accepted to participate. After the end of cardiac catheterization, the hemodynamicist applied the hemostatic device while in the hemodynamics room, removed the introducer and inflated the air bladder according to manufacturer's guidelines ( $15 \mathrm{ml}$ of air). Patients remained with the compression device for 4 hours (time recommended by the manufacturer) outside the hemodynamics room, seated in reclining seats. After the $3^{\text {rd }}$ hour, started the air bladder deflation by keeping it connected to the plunger, controlling the plunger with the thumb, and observing the puncture site. The total time for deflation was 1 hour, since every 15 minutes, $4 \mathrm{ml}$ of air were deflated, and in the last 15 minutes, the remaining $3 \mathrm{ml}$ of air. As the device was transparent, the puncture site could be visualized hourly. During this period until complete removal of the device, was evaluated the occurrence of hemorrhagic complications. Once hemostasis was reached after the $4^{\text {th }}$ hour, the device was removed, and patients were released home.

In all patients included in this study for elective exams (cardiac catheterization), were used $5 \mathrm{~F}$ or $6 \mathrm{~F}$ introducers, 5,000 IU of heparin and $70 \mathrm{ml}$ of non-ionic contrast agent - Iopamiron $370^{\circledR}$. 
The independent variables evaluated were age, weight, sex, comorbidities (systemic arterial hypertension, diabetes mellitus, dyslipidemia, previous acute myocardial infarction, previous cerebrovascular accident, chronic obstructive pulmonary disease, chronic renal failure, peripheral obstructive arterial disease), previous use of oral anticoagulant, oral antiplatelet, caliber of introducer caliber, number of use of devices, procedure time.

\section{Outcomes And fOllow-up}

The outcomes evaluated were the occurrence of hemorrhagic complications, namely hematomas and minor bleeding. Hematomas were classified as type $\mathrm{I}(\leq 5 \mathrm{~cm}$ diameter); type II ( $\leq 10 \mathrm{~cm}$ diameter $)$, type III $(>10 \mathrm{~cm}$, without reaching the elbow); type IV (hematoma extending beyond the elbow); and type $\mathrm{V}$ (any hematoma with ischemic injury of the hand $)^{(14)}$. Minor bleeding was any visible sign of blood during use and at the time of removal of the radial compression device (TR Band ${ }^{\circledR}$ ). In case of minor bleeding during the first 3 hours of wearing the device, was added a further $1 \mathrm{ml}$ of air, and normally performing deflation in the $3^{\text {rd }}$ hour. The success of the device was defined as obtaining adequate hemostasis at the end of the procedure with the TR Band ${ }^{\circledR}$ device with no need for conversion to compression dressing with elastic bandage $^{(10)}$. The follow-up was performed from application of the device to its removal. All patients were followed up by the service nurse, who performed the deflation, monitoring and removal of the device. In case of minor bleeding during the initiation of deflation ( $3^{\text {rd }}$ hour $)$ and removal of the device ( $4^{\text {th }}$ hour), air was again inflated until reaching $15 \mathrm{ml}$, and after 1 hour, the deflation started again with the same scheme as previously mentioned.

\section{ANALYSIS AND PROCESSING OF DATA}

Statistical analyzes were performed with the Statistical Package for Social Sciences (SPSS), version 22.0. Categorical variables were expressed as absolute numbers (n) and percentages (\%), and continuous variables were expressed as mean \pm standard deviation for those with normal or median distribution and interquartile range. In order to find associations between the variables, was used the chi-square test, and for the association between the independent variables and the occurrence of grouped outcomes (hematoma plus minor bleeding) was performed the unadjusted univariate logistic regression.

\section{ETHICAL ASPECTS}

The research project was approved by the Research Ethics Committee of institutions under number 1.338.057, year 2015, according to resolution 466/12. All patients signed the Informed Consent form.

\section{RESULTS}

A total of 244 patients were included, of which $62.0 \%$ were male, and the mean age was $63.5 \pm 10.9$ years. Table
1 shows the sociodemographic and clinical characteristics of the sample, and the most prevalent comorbidities were systemic arterial hypertension $(180 ; 73.8 \%)$ and dyslipidemia $(140 ; 42.8)$. In most patients, was used the $5 \mathrm{~F}$ introducer $(63.9 \%)$. The mean reuse of the TR Band ${ }^{\circledR}$ device was $23.42 \pm 17.05$, and new devices were used in $14(5.7 \%)$ patients. Regarding the duration of the examination, in 215 (88.1\%) patients, it was up to 30 minutes.

Table 1 - Sociodemographic and clinical characteristics - Porto Alegre, RS, Brazil, 2016.

\begin{tabular}{lc}
\hline Variables & $\mathbf{n}(\%)$ \\
\hline Male sex & $151(61.9)$ \\
Age* & $63.5 \pm 10.9$ \\
Systemic arterial hypertension & $180(73.8)$ \\
Dyslipidemia & $140(42.8)$ \\
Diabetes Mellitus & $85(34.8)$ \\
Prior cerebral vascular accident & $16(6.6)$ \\
Acute myocardial infarction & $33(13.5)$ \\
Chronic renal failure & $3(1.2)$ \\
Chronic obstructive pulmonary disease & $4(1.6)$ \\
Peripheral arterial obstructive disease & $6(2.5)$ \\
Prior use of oral anticoagulant & $6(2.5)$ \\
Prior use of antiplatelet & $155(63.5)$ \\
\hline
\end{tabular}

*Variable presented with mean/standard deviation.

Note: $(n=244)$.

\section{HemorRHAGIC COMPLICATIONS}

Regarding the outcomes evaluated, 25 patients (10.2\%) had hemorrhagic complications, with a predominance of minor bleeding during deflation of the device ( $3^{\text {rd }}$ hour) in seven $(2.8 \%)$ patients, and during removal of the device ( $4^{\text {th }}$ hour) in $15(6.2 \%)$ patients. These and other data are shown in Table 2.

Table 2 - Complications with the use of radial compression devices - Porto Alegre, RS, Brazil, 2016.

\begin{tabular}{lr}
\hline Hemorrhagic complications & $\mathbf{n}(\%)$ \\
\hline Type I hematoma & $3(1.2)$ \\
Minor bleeding & $22(9.0)$ \\
During first 3 hours of use & $7(2.8)$ \\
$3^{\text {rd }}$ hour (during deflation and removal of device) & $15(6.2)$ \\
\hline
\end{tabular}

Note: $(n=244)$.

There was no significant association between the most prevalent comorbidity in the sample (SAH - systemic arterial hypertension), the procedure time, the use of oral anticoagulant or antiplatelet and the incidence of hemorrhagic complications due to use of the TR Band ${ }^{\circledR}$ (data presented in Table 3). 
Table 3 - Association between independent variables and hemorrhagic complications - Porto Alegre, RS, Brazil, 2016.

\begin{tabular}{|c|c|c|c|}
\hline Independent variable & $\begin{array}{c}\text { Hemorrhagic } \\
\text { complications } \\
\text { n (\%) }\end{array}$ & $\begin{array}{c}\text { Crude OR } \\
(95 \% \mathrm{CI})\end{array}$ & $\mathbf{p}$ \\
\hline \multicolumn{4}{|l|}{ SAH } \\
\hline Yes & $18(10.0)$ & $0.90(0.37-2.42)$ & 0.832 \\
\hline No & 7 (10.9) & 1.00 & \\
\hline \multicolumn{4}{|l|}{ Procedure time } \\
\hline$<30 \min$ & $21(9.8)$ & 1.00 & \\
\hline $30-60 \mathrm{~min}$ & $4(13.8)$ & $1.4(0.40-4.27)$ & 0.505 \\
\hline \multicolumn{4}{|l|}{ Prior use of OAC } \\
\hline Yes & $1(16.7)$ & $1.78(0.09-11.67)$ & 0.604 \\
\hline No & $24(10.1)$ & 1.00 & \\
\hline \multicolumn{4}{|l|}{ Prior use of antiplatelet } \\
\hline Yes & $16(10.3)$ & $1.02(0.44-2.51)$ & 0.958 \\
\hline No & $9(10.1)$ & 1.00 & \\
\hline
\end{tabular}

SAH: systemic arterial hypertension; OAC: oral anticoagulant; OR: odds ratio; $\mathrm{CI}$ : confidence interval.

\section{DISCUSSION}

The use of radial access is recognized as a safe way of performing cardiac diagnostic catheterization and percutaneous coronary interventions (PCI), and in the literature, different compression methods for hemostasis have been described ${ }^{(1,3-4)}$. The present study examined the incidence of hemorrhagic complications in patients undergoing radial cardiac catheterization with use of a hemostatic device for radial compression during a 4-hour period. The knowledge of results achieved with new devices that are also handled by nurses with different deflation schemes is relevant for better defining the care actions, since these professionals are directly involved in the monitoring and evaluation of the puncture site after the procedure.

In a sample mostly composed of elderly men with $\mathrm{SAH}$, the results of this study showed the use of a compression device is safe in relation to the incidence of type I hematomas (1.2\%) and minor bleedings (9.0\%). The previous use of oral anticoagulant and antiplatelets did not influence the outcomes in the studied sample. In a previous study in which was evaluated hemostasis with use of the TR Band ${ }^{\circledR}$ device after radial puncture in patients with acute coronary syndrome and similar sociodemographic characteristics to this study, the incidence of hematoma was 3.4\% (all type II) (1). In another study, were compared two radial compression devices in patients after percutaneous coronary intervention, and was found that $20 \%$ of those using the TR Band ${ }^{\circledR}$ device presented minor bleeding ${ }^{(15)}$. Furthermore, the patients evaluated in our study underwent only a coronary diagnostic procedure, and generally, with a shorter duration than PCI.

Hemostasis obtained by pneumatic pressure of the device applied directly to the radial artery site has proved to be useful and easy to handle, in addition to allowing visualization of the puncture site, because the material is transparent. Equally important are the comfort and shorter recovery time of patients when using the radial access route, since they can move even with restricted movement of the catheterized upper limb.

Different compression devices are offered by the specialized industry. However, the quality of the product should be combined with patients' comfort and safety. A randomized clinical trial conducted with 790 patients compared two methods of radial compression. The results showed there were less reports of pain at the puncture site in patients using the TR Band ${ }^{\circledR}$ device compared to the group using the Radistop device of radial artery compression that is somewhat larger than the device ( $77 \%$ vs. $61 \% ; \mathrm{P}=0.0001$ ). In addition, the time to reach hemostasis was lower in the group using the TR Band ${ }^{\circledR}(5.32 \pm 2.29$ vs. $4.83 \pm 2.23 \mathrm{~h}$; $\mathrm{p}=0.004)$. However, both devices were effective and safe for hemostatic compression ${ }^{(16)}$. Health teams must be particularly attentive to the female sex (lower wrist diameter than that of men), length of stay of the introducer and higher pressure volume, since these factors have been associated with the presence of bruising and pain at the arterial puncture site ${ }^{(17)}$. It is important to remember that the air volume pushed into the bladder of the device must be adjusted according to the manufacturer's instruction $(15 \mathrm{ml})$, but there is no standardized information on the compression time. In a recent study, were evaluated three different intensities and compression periods. The results showed that a short period of 90 minutes of compression and the injection of less air than recommended $(10 \mathrm{ml})$ were sufficient for hemostasis ${ }^{(18)}$.

Recent data point to considering hemostatic devices as an economical and simple method of therapeutic option and non-invasive treatment of vascular complications, such as pseudoaneurysm and arteriovenous fistula ${ }^{(19-20)}$. Another feature of the compression device is that it can be reused several times, although a little more costly. The elastic bandage, in turn, is more economical, but disposable, that is, single use.

Maintaining arterial patency during hemostasis is the most important parameter for reducing the risk of arterial occlusion, which is one of the most concerning complications for the team. In spite of the low occurrence of this complication, data from the literature show it ranges between $1 \%$ and $10 \%$ in patients undergoing percutaneous coronary procedures ${ }^{(9)}$. In a randomized study involving 400 diagnostic coronary procedures, the incidence of early radial occlusion was $7 \%$, and of late occlusion was $5 \%{ }^{(21)}$. During the hemostasis process with use of the TR Band ${ }^{\circledR}$ device, the careful observation, prompt detection of hematoma and adequate handling of the device performed by nursing are key for avoiding further complications. This device allows flexibility in the inflation process, time of permanence and deflation, so that each service can adopt one of the more evidence-based strategies in relation to safety. New comparative studies, either with control group, or with other devices used for radial compression, are needed in order to ratify the device safety and present other deflation schemes.

Among the limitations of this study, there is the fact that ultrasonography was not performed for evaluation of arterial patency after device use, as well as the lack of a patient 
control group, since the device was used in all patients undergoing percutaneous radial procedure.

\section{CONCLUSION}

The use of the hemostatic device for radial artery compression during a 4-hour period proved to be safe in clinical practice and with a low incidence of hemorrhagic complications after elective cardiac catheterization. The contribution of this study to nursing care practice is presenting the results of a strategy of using a device after percutaneous procedures in cardiology. The results of this longitudinal study can support nurses' decision-making in their daily work.

\section{RESUMO}

Objetivo: Verificar a incidência de complicações hemorrágicas em pacientes submetidos a cateterismo cardíaco radial e com uso de pulseira hemostática para compressão arterial. Método: Estudo de coorte prospectivo, conduzido com pacientes submetidos a cateterismo cardíaco eletivo, em dois laboratórios de hemodinâmica no sul do Brasil. Para a hemostasia do sítio de punção arterial, foi utilizada a pulseira de compressão radial TR Band ${ }^{\circledR}$ por 4 horas. Os desfechos avaliados foram hematomas e sangramento menor. Resultados: Foram avaliados 244 pacientes, com idade média de $63,5 \pm 10,9$ anos, $61,9 \%$ do sexo masculino, $73,8 \%$ com hipertensão arterial sistêmica e 42,8\% dislipidêmicos. Ocorreram 1,2\% de hematoma tipo I e 9\% de sangramento menor depois da retirada da pulseira. Não houve associação significativa entre hematomas e sangramentos e os pacientes que faziam uso de anticoagulante oral ( $p=0,604)$ e uso prévio de antiplaquetário $(\mathrm{p}=0,958)$. Conclusão: $\mathrm{O}$ uso da pulseira hemostática para compressão da artéria radial mostrou-se segura na prática clínica e com reduzida incidência de hematomas e sangramento menor após cinecoronariografia por via radial.

\section{DESCRITORES}

Cateterismo Cardíaco; Hemodinâmica; Artéria Radial; Enfermagem Cardiovascular.

\section{RESUMEN}

Objetivo: Verificar la incidencia de complicaciones hemorrágicas en pacientes sometidos a cateterismo cardiaco radial y con el uso de pulsera hemostática para compresión arterial. Método: Estudio de cohorte prospectivo, conducido con pacientes sometidos a cateterismo cardiaco electivo, en dos laboratorios de hemodinámica en el sur de Brasil. Para la hemostasia del sitio de punción arterial, se utilizó la pulsera de compresión radial TR Band ${ }^{\circledR}$ por 4 horas. Los resultados evaluados fueron hematomas y sangrado menor. Resultados: Fueron evaluados 244 pacientes, con edad media de 63,5 10,9 años, el 61,9\% del sexo masculino, el 73,8\% con hipertensión arterial sistémica y el 42,8\% dislipidémicos. Ocurrió el 1,2\% de hematoma tipo I y el $9 \%$ de sangrado menor después de la retirada de la pulsera. No hubo asociación significativa entre hematomas y sangrados y los pacientes que hacían uso de anticoagulante oral ( $\mathrm{p}=0,604)$ y uso previo de antiplaquetario $(\mathrm{p}=0,958)$. Conclusión: El uso de la pulsera hemostática para compresión de la arteria radial se mostró segura en la práctica clínica y con reducida incidencia de hematomas y sangrado menor luego de cinecoronariografía por vía radial.

\section{DESCRITORES}

Cateterismo Cardíaco; Hemodinámica; Arteria Radial; Enfermería Cardiovascular.

\section{REFERENCES}

1. Santos MA, Borba RP, Moraes CV, Voltolini I, Azevedo EM, Cardoso CR, et al. Evaluation of radial artery patency after transradial catheterization. Rev Bras Cardiol Invasiva [Internet]. 2012 [cited 2017 June 13];20(4):403-7. Available from: http://www.scielo.br/pdf/ rbci/v20n4/v20n4a11.pdf

2. Hamon M, Pristipino C, Di Mario C, Nolan J, Ludwig J, Tubaro M, et al. Consensus document on the radial approach in percutaneous cardiovascular interventions: position paper by the European Association of Percutaneous Cardiovascular Interventions and Working Groups on Acute Cardiac Care** and Thrombosis of the European Society of Cardiology. Eurolntervention. 2013;8(11):1242-51.

3. Dall'Orto CC, Lopes RPF, Oliveira LDS, Cisari G, Souza Marques A, Perea JCC, et al. Intervenção coronária percutânea por acesso transradial em pacientes com infarto agudo do miocárdio com supradesnivelamento do segmento ST. Rev Bras Cardiol Invasiva [Internet]. 2012 [citado 2017 maio 30];20(3):282-7. Disponível em: http://www.scielo.br/pdf/rbci/v20n3/11.pdf

4. Tebet MA, Andrade PB, Andrade MVA. Segurança e eficácia da cateterização cardíaca direita e esquerda pelo acesso transradial comparado ao transfemoral: experiência inicial. Rev Bras Cardiol Invasiva [Internet]. 2008 [citado 2017 mar. 16];16(3):317-21. Disponível em: http:// www.scielo.br/pdf/rbci/v16n3/v16n3a13.pdf

5. Deuling JH, Vermeulen RP, van den Heuvel AF, Schurer RA, van der Harst P. A randomised controlled study of standard versus accelerated deflation of the Terumo radial band haemostasis device after transradial diagnostic cardiac catheterisation. Eur J Cardiovasc Nurs. 2017;16(4):344-51. DOI:10.1177/1474515116672123

6. Dal Piva C, Vaz E, Moraes MA, Goldmeyer S, Linch G, Souza EN. Desconfortos relatados pelos pacientes após cateterismo cardíaco pelas vias femoral ou radial. Rev Bras Cardiol Invasiva [Internet]. 2014 [citado 2017 jun. 13];22(1):36-40. Disponível em: http://www.scielo.br/ $\mathrm{pdf} / \mathrm{rbci} / \mathrm{v} 22 \mathrm{n} 1 / 0104-1843-\mathrm{rbci}-22-01-0036 . p d f$

7. Cardoso CO, Moraes CV, Voltolini I, Azevedo EM, Santos MA, Borba RP, et al. Influência da curva de aprendizado nos procedimentos percutâneos por via transradial. Rev Bras Cardiol Invasiva [Internet]. 2011 [citado 2017 maio 30];19(3):260-5. Disponível em: http://www. scielo.br/pdf/rbci/v19n3/v19n3a07.pdf

8. Frangosa C, Nobleb S. How to transform you into a radialist: tips and tricks. Cardiovasc Med [Internet]. 2011 [cited 2017 May 30];14(10):315-24. Available from: https://cardiovascmed.ch/resource/jf/journal/file/view/article/cvm/en/cvm.2011.01620/2011-11-051.pdf/

9. Sá BJL, Barros LFT, Brandão SCS, Victor EG. Interferência de introdutores reprocessados na oclusão da artéria radial após cateterismo cardíaco. Rev Bras Cardiol Invasiva [Internet]. 2013 [citado 2017 jun. 13];21(3):270-5. Disponível em: http://www.scielo.br/pdf/rbci/v21n3/13.pdf

10. Barbosa RA, Andrade MVA, Andrade PB, Rinaldi FS, Castro Bienert IR, Nogueira EF, et al. Utilização de pulseira compressora seletiva na prevenção da oclusão da artéria radial após procedimento coronário invasivo. Rev Bras Cardiol Invasiva [Internet]. 2014 [citado 2017 jun. 13];22(2):115-9. Disponível em: http://www.scielo.br/pdf/rbci/v22n2/0104-1843-rbci-22-02-0115.pdf 
11. Rashid M, Kwok CS, Pancholy S, Chugh S, Kedev SA, Bernat I, et al. Radial artery occlusion after transradial interventions: a systematic review and meta analysis. J Am Heart Assoc. 2016;5(1):e002686. DOI: 10.1161/JAHA.115.002686

12. Navarro Pérez L, Gil Ambrosio B, Aranda Nevado M, Muñoz Castro C, Lozano Marote E, Gea Valero M, et al. Comparación de los métodos de compresión de la arteria radial tras cateterismo cardíaco/ACTP (angioplastia coronaria transluminal percutánea), realizados en nuestro hospital. Enferm Cardiol [Internet]. 2009 [citado 2017 maio 30];16(47-48):43-6. Disponible en: https://www.enfermeriaencardiologia. com/wp-content/uploads/47_48_06.pdf

13. Assaf S, Freitas JO, Berti SL, Costa JR, Zbeid JAL. Comparação do curativo compressivo vs. pulseira hemostática após cateterização por via radial. Rev Bras de Cardiol Invasiva [Internet]. 2015 [citado 2017 jun. 13];23(4):271-5. Disponível em: http://www.rbci.org.br/pt/ comparacao-do-curativo-compressivo-vs-/articulo/S0104184316300133/

14. Bertrand OF, De Larochellière R, Rodés-Cabau J, Proulx G, Gleeton O, Nguyen CM, et al. A randomized study comparing same-day home discharge and abciximab bolus only to overnight hospitalization and abciximab bolus and infusion after transradial coronary stent implantation. Circulation. 2006;114(24):2636-43.

15. Dai N, Xu DC, Hou L, Peng WH, Wei YD, Xu YW. A comparison of 2 devices for radial artery hemostasis after transradial coronary intervention. J Cardiovasc Nurs. 2015;30(3):192-6. DOI:10.1097/JCN.0000000000000115

16. Rathore S, Stables RH, Pauriah M, Hakeem A, Mills JD, Palmer ND, et al. A randomized comparison of TR band and radistop hemostatic compression devices after transradial coronary intervention. Catheter Cardiovasc Interv. 2010;76(5):660-7.

17. Cheng KY, Chair SY, Choi KC. Access site complications and puncture site pain following transradial coronary procedures: a correlational study. Int J Nurs Stud. 2013;50(10):1304-13. DOl:10.1016/j.ijnurstu.2012.12.023

18. Dangoisse V, Guédès A, Chenu P, Hanet C, Albert C, Robin V, et al. Usefulness of a gentle and short hemostasis using the transradial band device after transradial access for percutaneous coronary angiography and interventions to reduce the radial artery occlusion rate (from the Prospective and Randomized CRASOC I, II, and III Studies). Am J Cardiol. 2017;120(3):374-9. DOI: http://dx.doi.org/10.1016/j. amjcard.2017.04.037

19. Hashimoto S, Shiraishi J, Kimura M, Nishikawa M, Yanagiuchi T, Ito D, et al. Usefulness of continuous compression using TR Band ${ }^{T M}$ for radial arteriovenous fistula following trans-radial intervention. J Cardiol Cases. 2015;12(6):192-4. DOI: https://doi.org/10.1016/j. jccase.2015.08.007

20. Ghanavati R, Ahmadi MA, Behnam B. Successful nonsurgical treatment of a radial artery pseudoaneurysm following transradial coronary angiography. J Tehran Heart Center [Internet]. 2017 [cited 2017 June 13];12(2):82. Available from: https://www.ncbi.nlm.nih.gov/pmc/ articles/PMC5558059/

21. Wagener JF, Rao SV. Radial artery occlusion after transradial approach to cardiac catheterization. Curr Atheroscler Rep. $2015 ; 17(3): 489$. DOI: $10.1007 / \mathrm{s} 11883-015-0489-6$ 